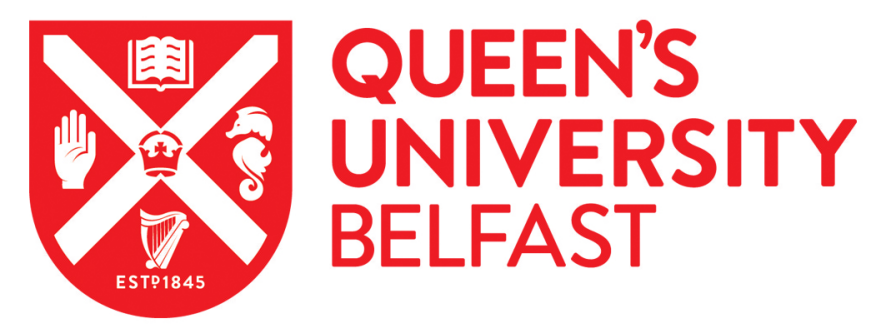

\title{
Human Rights Theory and Comparative International Law Scholarship
}

McCrudden, C. (2018). Human Rights Theory and Comparative International Law Scholarship. In L.

Waddington, \& A. Lawson (Eds.), The UN Convention on the Rights of Persons with Disabilities in Practice: A Comparative Analysis of the Role of Courts Oxford University Press.

\section{Published in:}

The UN Convention on the Rights of Persons with Disabilities in Practice: A Comparative Analysis of the Role of Courts

\section{Document Version:}

Peer reviewed version

Queen's University Belfast - Research Portal:

Link to publication record in Queen's University Belfast Research Portal

Publisher rights

Copyright 2018 OUP. This work is made available online in accordance with the publisher's policies. Please refer to any applicable terms of use of the publisher.

\section{General rights}

Copyright for the publications made accessible via the Queen's University Belfast Research Portal is retained by the author(s) and / or other copyright owners and it is a condition of accessing these publications that users recognise and abide by the legal requirements associated with these rights.

Take down policy

The Research Portal is Queen's institutional repository that provides access to Queen's research output. Every effort has been made to ensure that content in the Research Portal does not infringe any person's rights, or applicable UK laws. If you discover content in the Research Portal that you believe breaches copyright or violates any law, please contact openaccess@qub.ac.uk. 


\title{
Chapter 19 \\ Human rights theory and comparative international law scholarship
}

\author{
Christopher McCrudden
}

\section{Introduction}

Scepticism about human rights law is rampant, both at the political level and in certain parts of the academic community. This scepticism is not yet dominant by any means, but it is sufficiently pervasive, both on the left and the right of the political spectrum, for alarm bells to ring among human rights advocates. The resurgence of populist nationalism has further threatened the globalist and universalistic presuppositions of human rights. One of the effects of such scepticism has been to give a renewed urgency to the quest for the development of a robust, persuasive account of what human rights are, and what they are for. In particular, an important debate continues on the normative basis for human rights. One of the key debates in this context is the extent to which a normative theory of human rights should be consistent with human rights practice. ${ }^{1}$ Another, is how far the fact that human rights currently feature so significantly in international law and international relations stamps human rights generally with a particular normative understanding. ${ }^{2}$

Separately, until now, a strand of scholarship has been developed, which blends elements of international with comparative legal analysis to produce what has been termed comparative international law. This scholarship challenges the assumption that international law is the same everywhere. Its aim is to test the extent to which international law is understood differently in different parts of the world, and the extent to which an examination of the domestic application of international law generates a different understanding of the role of international law than that which emerges from examining the practice of international law internationally. ${ }^{3}$

The aim of this chapter is to bring these two strands of scholarship into conversation with each other, for their mutual benefit. Since the analysis of comparative international law often involves the analysis of international law across a range of subject areas, from human rights to trade, from the law of the sea to humanitarian law, it is important for that scholarship to take seriously the possibility that theories generated by a comparative international law analysis of domestic understandings of one area of international law may not explain what is happening in another area. Comparative international law needs, therefore, to be sensitive to the particular dynamics that each area of international law may generate. Thus, for example, as Lisa Waddington suggests elsewhere in this volume, it has been argued that human rights treaties are different from other international treaties, prompting judges to adopt a more monist approach to their relationship to domestic law, even in jurisdictions that traditionally adopt a dualist

${ }^{1}$ Charles Beitz, The Idea of Human Rights (OUP, 2011), 102 ff; Allen Buchanan, The Heart of Human Rights (OUP, 2014) (hereafter 'Buchanan, Heart of Human Rights'), 3-4.

${ }^{2}$ Buchanan, Heart of Human Rights, ibid; Patrick Macklem, The Sovereignty of Human Rights (OUP, 2015), passim; Steven Ratner, The Thin Justice of International Law: A Moral Reckoning of the Law of Nations (OUP, 2017).

${ }^{3}$ See Anthea Roberts, Paul Stephan, Pierre-Hugues Verdier, and Mila Versteg (editors), Comparative International Law (OUP, 2017, forthcoming). 
understanding of international law in general. ${ }^{4}$ An appreciation of the particular dimensions of human rights should help stimulate a more context-sensitive comparative international law scholarship. ${ }^{5}$

So, too, to the extent that a normative theory of human rights seeks to be consistent with the practice of human rights, it cannot avoid greater engagement with the domestic practice of human rights law, since that practice is a significant part of the whole. Studies such as the ones contained in this volume demonstrate further that the domestic practice of human rights also centrally involves the domestic courts' use of international human rights law, yet that dimension of human rights practice rarely features in accounts of the 'practice' of human rights that normative theorists of human rights derive their theories from. Human rights theorists who emphasise the 'international' dimensions of human rights need also to become more aware of the possibility that those international dimensions are themselves differently understood in different parts of the world, and consider what implications this may have for their normative understandings.

The human rights perspective that is adopted in this chapter also addresses an issue that is left largely unconsidered in the chapters of this volume: what are the implications of considering the law relating to disabled persons as part of the corpus of international human rights law, rather than as being sui generis? The CRPD is at one and the same time a specific treaty concerning disabled persons, and a human rights treaty. What, if any, is the common denominator that links taking a human rights perspective to disability issues with a human rights perspective to women's equality, the prohibition against torture, freedom from slavery, and the right to education? The question is what, if anything, distinguishes international human rights law from the rest of international law and also provides the glue that holds the ever-increasing material scope of specific human rights (freedom of religion, freedom of expression, the right to strike, the right to clean water, and a right to a basic minimum income, for example) together as a coherent, consistent whole?

The chapter is constructed as follows. In part 2 of the chapter, I suggest that comparative international law illuminates human rights practice in domestic courts, and provide an account, based on the findings of the authors in this volume and my earlier work on the use of the Convention on the Elimination of All Forms of Discrimination Against Women (CEDAW), of what we know about the use by domestic courts of international human rights law, and from that the domestic functions of international human rights treaties. I tentatively identify three aspects of that practice: international human rights law is only partly internationally-directed; domestic courts very seldom appear to be acting as 'agents' of international human rights law; and 'human dignity' (sometimes by itself, sometimes alongside 'autonomy' and 'equality') acts as an important meta-principle of the domestic use of international human rights law.

${ }^{4}$ Lisa Waddington, chapter $\mathrm{xx}$, this volume.

${ }^{5}$ Christopher McCrudden, Comparative International Law and Human Rights: A ValueAdded Approach, in Anthea Roberts, Paul Stephan, Pierre-Hugues Verdier, and Mila Versteg (editors), Comparative International Law (OUP, 2017, forthcoming). 
In part 3 of the chapter I ask if this tentative assessment is correct, and what implications this has for theories of human rights law. I present, briefly, an overview of some current debates in normative theorizing about human rights, focusing in particular on the distinction between practice-dependent and practice-independent theories of human rights, and (in the former) on what the 'practice' of human rights is considered to include. In part 4, I consider what a theory of human rights law consistent with this practice would look like. Part 5 concludes the chapter.

\section{Comparative international law and domestic courts' engagement with international human rights}

The CEDAW study identified several important features of the relationship between domestic courts and CEDAW. ${ }^{6}$ This volume shows a remarkably similar pattern in the domestic courts' engagement with the CRPD.

1. There is a significantly differential uptake of CEDAW in the courts of different regions of the world, and in the different issues to which CEDAW is applied in these different jurisdictions. So, too, this volume demonstrates that there are very considerable differences in the extent to which different courts refer to the CRPD, and in the provisions to which they refer.

2. The CEDAW study distinguished between three principal methods by which CEDAW entered the judicial decision: the judges own research; existing use internal to the legal system influencing judges (where 'internal' includes ECHR and EU law in those states in which that law applies); and the arguments of lawyers representing those before the court (including, in some cases, intervenors and amicus curiae). These methods appear to cover also the variety of ways in which the CRPD enters the judicial system.

3. It was frequently the case that judges referred to CEDAW sua sponte, and this is also the case as regards CRPD, with examples in both studies where CEDAW and CRPD are referred to by judges spontaneously in both common law and civil law jurisdictions, and irrespective of whether there was a perceived obligation to refer to international agreements that had been ratified by the state in which the Court had jurisdiction.

4. Although there did not appear to be significant divergence between jurisdictions as to whether judges refer to CEDAW sua sponte, there did appear to be significant difference within the same jurisdictions, with some courts citing CEDAW more than others. This is also the case regarding the CRPD.

5. Some judges cited CEDAW more frequently in their judgments than others, and this was also the case regarding the CRPD. Evidence suggests that, in a large number of cases, courts or individual judges decide to refer to the CRPD on their own volition without

${ }^{6}$ Christopher McCrudden, CEDAW in national courts: a case study in operationalizing comparative international law analysis in a human rights context, in Anthea Roberts, Paul Stephan, Pierre-Hugues Verdier, and Mila Versteg (editors), Comparative International Law (OUP, 2017, forthcoming). 
prompting from an external source. However, whereas there was some evidence that there was a gender effect, with women judges citing CEDAW proportionately more than male judges, no equivalent identity group was identified in the case of judges citing the CRPD.

6. Within the group of cases in which there is a serious engagement with CEDAW, there is a relatively high proportion in which Non-Governmental Organisations or government human rights or equality agencies are involved, sometimes using amicus curiae interventions. In the case of the CRPD, however, an equivalent correlation was not so clearly identified. Research for this book identified a relatively small number of amicus curiae interventions which included references to the CRPD. In general, there is therefore little evidence in the jurisdictions considered that amicus curiae briefs from human rights organizations or other sources are influencing court practice with regard to the CRPD, except perhaps in the United Kingdom and Mexico.

7. Once the court is seized of CEDAW or the CRPD, a major question relates to the relationship that the domestic court conceives itself as having with other interpreters of CEDAW or CRPD. The question is where along a continuum between autonomous interpretation (where the domestic court considers that it alone has authority to interpret CEDAW or the CRPD in the domestic legal context) and deference (where the domestic court considers that another body has the principal interpretative authority, to which it should defer) the domestic court's approach lies. We see in the cases included in the dataset examples of both orientations, with most reflecting a strongly autonomous approach, but some others reflecting a more deferential approach. The latter is somewhat more identifiable in the case of CEDAW than in the case of the CRPD, but to the extent that the more deferential approach is reflected in references by domestic courts to the CEDAW Committee, it is worth noting that the CEDAW Committee had had the chance to develop a larger body of interpretive guidance at the time of the CEDAW study than the more recent CRPD Committee has had at the time of the studies in this volume.

8. It is particularly striking, however, that I identified only one out of over 300 cases in which the domestic court sought directly to interpret a provision of CEDAW in light of how the courts of other states and foreign courts interpreted the same provision. The research for this volume similarly identified only one such case regarding CRPD, in which an Indian court drew on a judgment of the Court of Justice of the European Union in the $Z$ case. ${ }^{7}$ Courts did not, in the overwhelming majority of cases, tend to refer to the interpretation of CEDAW or CRPD by other foreign domestic courts, even when this practice is otherwise relatively frequent in the context of the interpretation of national constitutional and domestic statutory provisions.

9. The domestic legal status attributed by domestic courts to both CEDAW and CRPD varies considerably between different states. In both studies, two different types of legal status were accorded, with some states according a monist status, and others a dualist status. Both studies identified a variety of different elements influencing these statuses of

\footnotetext{
${ }^{7}$ [This book, Chapter ??, section ??.
} 
the CRPD, and different ways in which courts regarded the CRPD as relevant, but there is no indication in general that the distinction between monist and dualist systems was a particularly significant factor in the context of either CEDAW or the CRPD.

10. In only a few states, CEDAW and the CRPD were used in practice as the basis for direct litigation claims - they were given 'direct effect'. In the case of CRPD, however, given the very limited number of cases considering the issue of direct effect, reaching any general conclusions from a comparative perspective, ${ }^{8}$ other than that courts are, for the most part, not considering this issue, would be difficult.

11. In a significantly greater proportion of states, CEDAW was given indirect interpretative effect, meaning that it is used primarily as the basis for interpreting other provisions of domestic or relevant international law, such as the domestic constitution, other international conventions, applicable customary international law, or legislation that applies in the state concerned. So, too, the research for this volume has revealed a wide range of cases in which courts relied on the CRPD in interpreting domestic law.

12. In both cases, CEDAW and the CRPD were primarily used simply to bolster an interpretation the court was seemingly likely to reach any way, although in a small number of cases CEDAW and the CRPD seem to have pushed the court to develop a more progressive interpretation of a domestic provision. Where CEDAW is taken into account in judicial decisions, this is most frequently the case in a situation where the primary function of CEDAW is indirect, to assist in the interpretation of another legal norm which operates in that legal system, which may be a constitutional provision, a statutory provision, or the common law.

13. Where substantive interpretation of CEDAW or the CRPD is to be found, there is relatively little substantive conflict between domestic courts in the interpretation of CEDAW and CRPD norms, although making that judgment is significantly subjective. This relative homogeneity of substantive interpretation is to be found both in the conception of rights that is considered to be embodied in CEDAW or the CRPD, and in the substantive result that emerges from the application of CEDAW and the CRPD to particular areas of dispute.

14. Where domestic courts found the CRPD or CEDAW to be relevant and a source of law which helped them resolve the case at hand, the fact that it was a provision of international law was regarded as important.

15. Where courts considered the CRPD or CEDAW as relevant, they tended to regard it as having a static or fixed meaning, and not susceptible to a variety of meanings thereby depriving the domestic courts of any significant role in interpreting the Convention.

${ }^{8}$ In Spain, the CRPD was regarded as directly applicable - but the courts do not seem to have examined the criteria which had to be met for this to happen, see [Spanish chapter]. In Germany Art. 5 CRPD (but no other article) was regarded by courts as meeting the criteria for being directly applicable in abstract - but it was not given direct effect in any case in that the issue could be resolved using domestic law, see [German chapter]. 
16. Neither study, on the whole, revealed a significant pattern of domestic courts acting as agents or trustees of the CRPD or CEDAW, although there are notable exceptions in both cases. Rather, for the most part, courts see themselves as 'agents of domestic law' which utilize the CRPD and CEDAW to help them resolve a specific domestic issue rather than enforce an internationally recognized right or encourage the State Party to comply with its CRPD or CEDAW obligations.

17. Courts generally saw themselves as utilizing the CRPD in a domestic context and as domestic actors in most judgments in which they referred to the CRPD or CEDAW, although there were some notable exceptions to this trend. The fact that implementing EU law entails attention to the CRPD is, however, worthy of mention as in those cases judges can perhaps be seen acting as agents of EU law, and similarly in the case of the ECHR.

18. When courts adopt a more teleological approach to interpretation, in which the court attempts to determine the 'end' or 'teleos' of CEDAW and interpret its provisions in light of that, principles of very considerable generality, which in this context I termed 'meta-principles', come significantly into play. The concept of (human) dignity is one of the meta-principles, along with 'equality' and 'autonomy' that is also identified in cases citing the CRPD. ${ }^{9}$

\section{Implications for human rights theory}

9 See, for example, Australia: Patrick's Case [2011] VSC 327 (Supreme Court of Victoria), para 333 (per Bell J.); Julie Ann Nicholson \& Ors v. Timothy Knaggs \& Ors [2009] VSC 64 (Supreme Court of Victoria), para 18 (per Vickery J); Collier v. Austin Health, [2011] VSC 344 (Supreme Court of Victoria), para 29 (per Bell J); Abrahams (by his litigation guardian The Public Trustee of Queensland) v Abrahams [2015] QCA 286 (Supreme Court of Queensland (Court of Appeal), para 26; ZEH (Guardianship) [2015] VCAT 20151 (Victorian Civil and Administrative Tribunal), para 51. India: Ranjit Kumar Rajak $v$ State Bank of India 2009(5) BomCR 227 (High Court of Bombay), para 27; Jeeja Ghosh v Union of India AIR 2016 SC 2393 (Supreme Court of India), paras 36-38; Lalit v Government of NCT, Writ Petition (Civil) No. 8568 of 2009 (decided on 2 December 2010) (High Court of Delhi), para 16. Ireland: XY (a minor suing by her guardian ad litem, Raymond McEvoy) v Health Service Executive and the Attorney General and Irish Human Rights Commission (notice parties) (No.2) [2014] 1 I.L.R.M. 170; [2013] IEHC 490 (High Court), at para. 16 (per Birmingham J). Italy: Judgment No. 251/2008 (Italian Constitutional Court), para 8 of Conclusions in Point of Law; Council of State No. 5185/2011 of 16 September 2011. Kenya: Wilson Siringi v Republic Crim. App [2014] eKLR (Appellate Court), para 16. Argentina: MMMG c/ Ministerio de Economía (Estado Nacional) s/ Incidente - familia, Corte Suprema de Justicia de la Nación, 5 July 2011; FR c/ INSSJYP s/ Ley de discapacidad, 27 March 2015, (Appeals Chamber of Mar del Plata). European Court of Human Rights: Bouyid $v$. Belgium (Application no. 23380/09, judgment 28 September 2015); Stanev v. Bulgaria (Application no. 36760/06, Grand Chamber Judgment 17 January 2012) (Judge Kalaydjieva); Ruiz Rivera v. Switzerland (op cit). Ruiz Rivera v. Switzerland (Application no. 8300/06, Judgment 18 February 2014 (Concurring Opinion of Judge Sajó). Mexico: Judgment 989/2014 (Supreme Court of Justice of the Nation). Spain: Judgment 478/2014, of 2 October 2014 (Civil Chamber of the Supreme Court); United Kingdom: P v Cheshire West and Chester Council and another; P and Q v Surrey County Council [2014] UKSC 19 (UK Supreme Court), para 45 (per Lady Hale). 
Considerably more research concerning the engagement by domestic courts with other areas of international human rights law needs to be undertaken before it could be said with any degree of assurance that these patterns, identified in the CEDAW and CRPD studies, are generalizable across human rights. For the moment, these patterns, and the explanations that seek to explain them are plausible hypotheses. Nevertheless, it is not too early to begin to think about the implications, if they prove to be supported elsewhere. In particular, what are the implications for a theory of human rights?

I suggest that three implications of these results in the area of human rights may be of particular importance. First, the empirical results cast an interesting light on the old, and deeply contested territory, of how we should understand the different accounts we have of the evolution of human rights. One of the key issues in the debates between these different histories of that evolution is whether we see continuity or discontinuity. Is there a continuity of values across space and time, which we see currently fraying at the edges? Or has there always been a discontinuity of values across space and time, and we are merely seeing confirmation of this? Or are we observing some sort of co-evolutionary process, where human rights evolve out of a continuing discourse among the various actors and institutions? We might hope that thorough comparative international human rights law promises to throw new light on this old debate. The picture that emerges from these empirical studies is, however, quite unclear. The relative absence of significant divergence at the domestic level in the judicial interpretation of significantly openended norms gives little support to a radical discontinuity thesis, but in most cases we cannot say that there were common interpretations; rather, courts were simply addressing different issues in their judgments. Nevertheless, (at least in the case of CEDAW) there is sufficient divergence identifiable in those cases in which a similar issue was being addressed for us to have to acknowledge, albeit tentatively, a not insignificant pluralism in the domestic judicial understanding of the international norms.

Second, these findings, if confirmed, appear to cast some doubt on recent constructivist accounts of why international human rights standards come to be received into the practice of states, what Harold Koh has termed 'norm-internalisation,' ${ }^{10}$ Goodman and Jinks, for example, identify three types of social mechanisms of norm internalization: ${ }^{11}$ material inducement (states are influenced by others applying 'material rewards and punishments'), ${ }^{12}$ persuasion (states are 'convinced of the truth, validity, or appropriateness of a norm belief, or practice'13), and acculturation (a state grows to emulate the practice of other states with which the state wishes to establish or maintain good relationships ${ }^{14}$ ).

Constructivist accounts have frequently focused on state decisions regarding ratification of international norms, and in particular how 'states' come to decide that they will formally join new

${ }^{10}$ Harold Hongju Koh, Why Do Nations Obey International Law?, 106 Yale Law Journal 2599, 2615-34 (1997).

${ }^{11}$ Ryan Goodman and Derek Jinks, Socializing States: Promoting Human Rights Through International Law (OUP, 2013) (hereafter Goodman and Jinks).

${ }^{12}$ Goodman and Jinks, at 23.

${ }^{13}$ Goodman and Jinks, at 24.

${ }^{14}$ Goodman and Jinks, at 25-26. 
or existing human rights treaty regimes, and have paid less attention, thus far, to the important question of how 'states' come to internalize these norms other than by the decisions of foreign ministries, cabinets, and legislatures. Less attention has, so far, been given to the question of how international human rights norms come into, and are applied by, domestic courts. ${ }^{15}$ Comparative international human rights legal scholarship shows how legal norm internalization may also occur through the influence of judicial decision-making. If my suggestions are correct that a significant driver in the judicial adoption of international human rights norms is their utility in addressing domestic issues, then the extent to which this judicial norm internalization occurs through social processes of persuasion and acculturation, in which courts are primarily concerned with relevant external and international communities, is questionable. Yet relatively little empirical work has been done on norm internalization of international human rights law at the domestic judicial level, ${ }^{16}$ and it is to be hoped that the emergence of comparative international human rights law will encourage other scholars to engage in further study of these issues.

Third, the ideology of international human rights law is sufficiently universalistic that if a comparative international human rights analysis finds a deep pluralism operating in practice, this will seem deeply troubling to some. ${ }^{17}$ Some might well view empirical support for the hypothesis that international human rights law plays different functions in different domestic contexts as constituting an existential threat to the international human rights project. My own view, however, is that rather than challenging the normative foundations of human rights, it urges us on to attempt to produce a normative theory that is more in sync with empirical reality. But this approach assumes that a normative theory of human rights can and should be based, at least in part, on the practice of human rights, and that is a deeply contested idea in the current philosophy of human rights, in two particular respects that are relevant for the discussion in this chapter: first, should a normative theory attempt to reconcile itself with human rights practice; and if so, second, what exactly do we mean by 'human rights practice'?

There are now several sustained attempts by political philosophers to theorize about the meaning, scope, and justification of human rights. One significant difference between these varied philosophical approaches has to do with methodology: where do we start if we want to provide a normative account of human rights? One strand of philosophical theorizing has attempted to provide accounts that begin from the practice of human rights (practice-dependent theories). One of the most prominent exemplars of this approach is that taken by a group of philosophers who have been identified as adopting a 'political' approach, an approach particularly associated with

15 Helmut Philipp Aust, Alejandro Rodiles and Peter Staubach, Unity or Uniformity? Domestic Courts and Treaty Interpretation, 27 Leiden Journal of International Law 75 (2014) (hereafter Aust, et al.)

${ }^{16}$ For an early example, see Enforcing International Human Rights in Domestic Courts (Benedetto Conforti and Francesco Francioni (eds., 1997). See also Gabor Halmai, Domestic Courts and International Human Rights, in Sage Handbook of Human Rights (Anja Mihr and Mark Gibney, eds., 2014), 749. For broader studies, focusing on the role of domestic courts in implementing treaties in general, see International Law and Domestic Legal Systems, Incorporation, Transformation, and Persuasion (Dinah Shelton, ed., 2011) and The Role of Domestic Courts in Treaty Enforcement: A Comparative Study (D. Sloss, ed., 2014).

17 David Kennedy, One, Two, Three, Many Legal Orders: Legal Pluralism and the Cosmopolitan Dream, 3 N.Y.U. Rev. L. \& Soc. Change 641, 649 (2007). 
John Rawls, ${ }^{18}$ Joseph Raz, ${ }^{19}$ and Charles Beitz, ${ }^{20}$ among others. In contrast, other philosophers provide accounts based initially on a priori reasoning (practice independent). There are several examples of this approach, but the most prominent recent exemplars are John Tasioulas ${ }^{21}$ and James Griffin. ${ }^{22}$ They are sometimes described as adopting an 'orthodox' or 'moral' approach.

I broadly agree with the general strategy of distinguishing practice-dependent and practiceindependent approaches, but I am attracted by this distinction only as an initial heuristic device. In practice, the sharp distinction sometimes drawn between these two approaches is overdrawn. Contrary to current practice-dependent philosophical approaches to human rights, and somewhat paradoxically, more attention to actual legal practice questions whether 'practice-dependent' approaches should be quite as dismissive of 'orthodox' or 'moral' approaches as they are. Although Macklem recognizes that the international human rights norms 'inescapably possess normative dimensions,' he argues that 'forays into moral theory to determine their normative content remain tethered to the international legal order. ${ }^{23}$

But this does not seem to me to reflect the legal practice identified in the CEDAW and CRPD studies. Quite often, the domestic judicial practice is tethered to 'orthodox' understandings of human rights, hence the popularity of discourse drawing on concepts such as human dignity. It is unconvincing to argue that 'human dignity' is 'tethered to the international legal order,' given that its purpose is precisely not to tether it to any particular institutional manifestation, national or international. It claims, after all, to be a universal principle. The normativity of concepts such as human dignity 'is one that is internal ... to international law,' in Macklem's words, but it is also 'external' to international law, including in national law. In other words, a practice-dependent approach is incomplete as it stands at the moment. A preferable approach is one refined by the inclusion of distinctively 'orthodox' elements, in particular, the idea that human rights derive their normative power from being seen as in pursuit of normative meta-principles, such as human dignity.

All this assumes, of course, that the 'practice' of human rights includes the practice of domestic courts. For legal scholars, this might seem an uncontroversial assumption, but it is not. Despite the fact that the jurisprudence of human rights is part of human rights practice in a broad sense, no prominent practice-dependent philosopher, including those from the 'political' tradition, accords any significant place to the contemporary jurisprudence of domestic courts in their accounts of human rights practice. This is both puzzling and a significant gap in practicedependent approaches. Recent philosophical accounts of human rights that purport to be based on the actual practice of human rights are flawed, therefore, in so far as they seldom engage in a

18 John Rawls, The Law of Peoples, rev ed (Cambridge, MA: Harvard University Press, 2001) [Rawls, Law of Peoples].

19 Joseph Raz, 'Human Rights without Foundations' in Samantha Besson \& John Tasioulas, eds, The Philosophy of International Law (Oxford: Oxford University Press, 2010) 321.

${ }^{20}$ Beitz, supra note 1 .

${ }^{21}$ John Tasioulas, 'Towards a Philosophy of Human Rights' (2012) Current Legal Probs 1 at 22; John Tasioulas, 'Are Human Rights Essentially Triggers for Intervention?' (2009) 4 Philosophy Compass 938.

22 James Griffin, On Human Rights (Oxford: Oxford University Press, 2008).

${ }^{23}$ Ibid at 22. 
sustained way with the international judicial interpretation of human rights guarantees, focusing instead mainly on the international political practice of human rights (Rawls, ${ }^{24} \mathrm{Raz}^{25}$ ), on the constitutional text and the limited judicial practice of one state (Jürgen Habermas ${ }^{26}$ ), on the international treaty texts (Allen Buchanan ${ }^{27}$ ), or on historical developments without appreciating the role of judicial practice in that history (Hans Joas ${ }^{28}$ ).

One cannot, I suggest, understand the role of international human rights law without situating it within the context of international law more broadly, including the judicial interpretation of that law. I equally do not think one can understand international human rights law without situating it within human rights law more broadly, including transnational and domestic human rights law. I suggest, therefore, that if we are interested in providing an account of the role of international human rights law, we should integrate more fully what is occurring at the national level in human rights law into the international human rights narrative, including what domestic courts do. I want to make a case, therefore, for the inclusion of the activities of judicial institutions (national and international) in accounts of human rights that purport to grow from human rights practice. A comparative analysis of international human rights law, therefore, provides a necessary corrective to an overly blinkered approach to our understanding of 'human rights practice'.

I do not want to be seen to be suggesting that judicial engagement with international human rights should dominate our understanding of human rights 'practice'; nor do I want to suggest that human rights practice should be conceived as primarily legal. Rather the contrary. I want to suggest that a broader understanding of human rights practice would take more seriously the institutional context in which human rights operate. Philosophical approaches require a deeper engagement with the fact that so many different institutions are so heavily involved. This poses a challenge, in particular, to those seeking to project a view of human rights law as laying down authoritative standards. More often, human rights provide the forum and the language for continuing debate and argument, but little closure. I agree, therefore, with Macklem's description of 'human rights as legal sites of moral and political contestation over fundamental questions about the structure and operation of international law' itself $^{29}$ and that in certain context at least these debates are cast 'in distinctively legal terms. ${ }^{30}$

\section{Towards a theory of human rights law consistent with practice?}

How should we account for the pattern of domestic judicial engagement with international human rights law? In my article in the American Journal of International Law concerning the domestic interpretation of CEDAW, I argued that the observable patterns of references to CEDAW in national level courts may result, to a significant degree, from the combination of four

${ }^{24}$ Rawls, Law of Peoples, supra note 18.

${ }^{25}$ Raz, 'Human Rights,' supra note 19.

26 Jürgen Habermas, 'The Concept of Human Dignity and the Realistic Utopia of Human Rights' (2010) 41:4 Metaphilosophy 464.

${ }^{27}$ Buchanan, Heart of Human Rights, supra note 1.

${ }^{28}$ Hans Joas, The Sacredness of the Person (Washington, DC: Georgetown University Press, 2013).

${ }^{29}$ Ibid at 2.

${ }^{30}$ Ibid at 26. 
elements that, taken together, are unique to international human rights law in this setting: that it is international law; that it concerns human rights; that it is law; and that it is being applied domestically. ${ }^{31}$ The first three elements combined offer domestic courts a set of norms that is consensus based ('international') and purportedly universal ('human rights'), which courts and legal advocates are able to draw on ('law'), in order to help address domestic concerns or escape from otherwise troublesome 'domestic' constraints. This explanation seems also to explain the similar pattern found in this volume regarding domestic courts' engagement with the CRPD.

Assuming it is generalizable, is a normative theory of human rights possible, one that is broadly consistent with this account of practice, takes seriously the moral and ethical underpinnings of human rights, but recognizes that this aspect of practice is only one manifestation of a complex web of institutional responses to international human rights law? I think so, and my aim in the remainder of this chapter is to advance this theory, provisionally and tentatively. ${ }^{32}$

My starting point looks strikingly Hartian, but it is the Hart of Punishment and Responsibility ${ }^{33}$ rather than the Hart of The Concept of Law, ${ }^{34}$ or the Hart of 'Are There Any Natural Rights?' ${ }^{35}$ Hart distinguishes at least two justificatory issues in constructing a normative theory of punishment. First, what is the 'general justifying aim' of the system? What justifies the creation and maintenance of such a system - what good can it achieve, what duty can it fulfil, what moral demand can it satisfy? Second, he distinguishes the methods adopted to further this system, including who may properly be punished and how the appropriate amount of punishment should be determined. We need to distinguish, in other words, the general justifying aim of the system, from how we pursue that aim - crudely, a means/end distinction. Hart argues that we find that quite different (and even, potentially, conflicting) values are relevant to these different issues about punishment and that any complete normative account of punishment will have to find a place for these differing values - in order to help us find some way of deciding between them when they conflict.

I think that this general strategy is also useful in analyzing the human rights 'system' and the place of human dignity in it. Incidentally, Allen Buchanan's recent book adopts a similar starting point. ${ }^{36}$ We need to modify the Hartian strategy in one major respect, however. I do not

31 Christopher McCrudden, 'Why Do National Court Judges Refer to Human Rights Treaties? A Comparative International Law Analysis of CEDAW' (2015) 109:3 AJIL 534. Convention on the Elimination of All Forms of Discrimination against Women, 18 December 1979, 1249 UNTS 49.

32 This section borrows significantly from Christopher McCrudden, Is the Principal Function of International Human Rights to Address the Pathologies of International Law? A Comment on Patrick Macklem's The Sovereignty of Human Rights, (2017) University of Toronto Law Journal (in press).

${ }^{33}$ HLA Hart, Punishment and Responsibility: Essays in the Philosophy of Law, 2d ed (Oxford: Oxford University Press, 2008).

${ }^{34}$ HLA Hart, The Concept of Law, edited by Penny Bulloch \& Joseph Raz, 3d ed (Oxford: Oxford University Press, 2012) (with an introduction and notes by Leslie Green).

${ }^{35}$ HLA Hart, 'Are There Any Natural Rights?' (1955) 64:2 Philosophical Review 175.

${ }^{36}$ Buchanan, Heart of Human Rights, supra note 1. 
assume, as I think Hart sometimes seems to, that there must be a set of justifications there to be identified. Normative theorists must be open to the possibility that the practice cannot be justified, if there is no coherent set of moral justifications in the human rights context. I believe, in fact, that a set of normative justifications does exist, but we cannot simply assume that they must exist.

My suggestion is that the general justifying aim of human rights, identified from the practice of human rights, is the pursuit of human dignity, or some equivalent type of metaprinciple, whereby each human person, qua human person, is seen to possess an intrinsic worth that should be respected. I will call this the ontological claim. This is the concept that above all others is most commonly found in all international human rights instruments and, increasingly, in judicial practice and that appears to be regarded as foundational to human rights, as a whole.

However, although mine is a foundationalist claim, it is a weak foundationalist claim. In particular, we should not infer that the idea of human dignity instantiates any particular understanding of what the value of the human person consists of. It is not necessarily an understanding of dignity as autonomy, or of equality, or of communitarianism. In particular, it is not necessarily a liberal agenda. It is simply a claim that a human person has a moral worth as a person. I suggested in an earlier article that two elements have developed which limit the methods of pursuing this aim. ${ }^{37}$ These also are weak claims. First, some forms of conduct between persons are inconsistent with respect for this intrinsic worth (the relational claim). Second, the state exists for the individual, not vice versa (the limited state claim). The different understandings of each of these elements of the concept of human dignity indicate that different conceptions of human dignity, and different ways of pursuing it, are identifiable. The fault lines lie in disagreement as to what the intrinsic worth of persons consists in, what forms of treatment are inconsistent with that worth, and what the implications are for the role of the state. Weak though it is, however, the general justifying aim I have identified also provides a moral foundation for the system of human rights as a whole.

Note that I distinguish between human dignity and human rights. Human rights are to be seen as one strategy by which human dignity is pursued. It is not the only way in which it is pursued. The human rights system, then, consists of a set of norms that are institutionalized in related, but different, sets of practices: international, diplomatic, legal, constitutional, moral, revolutionary, and so on. In this, my approach is clearly influenced by Rawls in the sense that human rights do not just exist out there floating free but, rather, they have to be institutionalized to make them 'real.' Where I differ from Rawls is that I do not limit the institutionalization of human rights to the narrow range of international political institutions that he appears to.

Each of these elements of human rights practice has its own normative foundation in play that means that different rights aiming to further human dignity will (perhaps even should) result. There is, for example, a set of legal institutional considerations and constraints that mean that not all legal human rights are also moral human rights, and vice versa. Dignity also provides a critique of the human rights system. It is perfectly compatible with my approach - indeed my approach requires - that each area of human rights practice can, and should, be scrutinized for whether it

${ }^{37}$ Christopher McCrudden, 'Human Dignity and Judicial Interpretation of Human Rights' (2008) 19(4) European Journal of International Law 655. 
adequately pursues human dignity. It provides, therefore, a constraint on what human rights can consist of in each of these areas of practice, but, again, it is a weak constraint. It would reject an attempted justification of an approach to the pursuit of human rights that simply handed all power over to an unconstrained state, but, beyond that, it is deeply contested as to what is required.

In practice, these critiques are both internal and external (using these terms in a somewhat difference sense than before) to these areas of practice. Each develops over time particular ways of understanding the general justifying aim and, therefore, provides the opportunity for an immanent critique of the understanding of human rights within that area. But the fact that there are different areas of human rights practice means that there is the possibility that one area of practice's understanding of the general justifying aim may conflict with that of another, and this both encourages and facilitates the external critique of the approach to human rights adopted in each area of practice.

This is highly relevant to the relationship between practice-dependent and practiceindependent approaches. Judges, for example, sometimes need to draw on philosophical understandings of human rights, irrespective of whether these philosophers claim to be practice dependent or practice independent. Given this, we should not be surprised to find that judges are likely to engage with practice-independent approaches, including those approaches that would be considered to be 'orthodox.' To that extent, therefore, judicial practice can and does accommodate insights from these philosophers, and, in doing so, the judicial practice of human rights changes and adapts as new issues arise or old issues are reconsidered. When practice-dependent philosophers then take judicial practice seriously into account, as it is strongly suggested they should, they will have to describe a practice that incorporates to some extent practice-independent philosophers of human rights as well as practice-dependent philosophers. Both will have become part of the practice of human rights.

Thus far, I have suggested an approach that combines a weak general justifying aim based on dignity, with a recognition that the pursuit of that aim may involve the adoption of human rights in different institutional forms, in different contexts, and with different content. This is vital for understanding the normative pluralism of human rights practice, because the pursuit of dignity through according human rights is necessarily constrained by the normative understandings of each institution and its institutional logic, set in particular contexts.

Each area of practice will also have its own method of discourse. In practice, what we see is that human rights arise out of contestation, power struggles, and ideological conflict within and between these different areas of practice. And some (indeed, many) of those conflicts concern the very understanding of what it means to respect the human worth of the person, and the role of the state in this understanding. Discourse, debate, and contestation are not marginal to the practice of human rights, but central to it, and this contestation takes place as much within particular areas of practice as between them.

Under my suggested approach, the lack of resolution of the contradictions in the international adjudication of human rights law disputes, for example, is not to be regarded as a failure but, rather, as an essential element of the practice of human rights. The practice of human rights adjudication, human rights law, and human rights courts, becomes the site of a provisional 
and (politically) temporary accommodation that helps us to live together, despite the basic conflicts that are brought to court. We agree to abide by the decisions of a decision maker whom we agree, for the moment at least, is broadly legitimate and competent. Human rights adjudication is seen as an enterprise in which the judge is not only engaging with the dispute in hand, attempting to arrive at a justified and reasoned judgment, but also doing so in a context in which the nature of the judge's resolution of the question is provisional.

My approach rejects the view that the pluralism existing at present in human rights adjudication is chaotic in ways that are dysfunctional. My approach accepts that human rights law, for example, is pluralistic but argues that this pluralism is not randomly chaotic, or dysfunctional, or temporary. From this perspective, international human rights law is seen as providing a forum in which tensions and conflicts over some of the most basic ethical, epistemological, and ontological questions are engaged. From this perspective, it would be puzzling if a pluralistic system of human rights had not emerged. The pluralism of the system is not, therefore, a problem to be overcome but, rather, a critically important and central aspect not only of the proper understanding of human rights law but also of human rights discourse generally, one to be recognized and cherished for the critical reflexive function it encourages.

My preferred approach is not, therefore, a static model but, instead, one that is open to continuing change, including change involving the continued suitability of international human rights law to provide the forum in which these contested questions are considered at all. Not only is the actual result in a particular case open to revision, but the judge's legitimacy in arriving at the decision at all is also provisional. That is an important and defensible role for human rights law, and human rights courts, but it is a modest one.

\section{Conclusion}

This sketch challenges several aspects of recent philosophical discussions of human rights. Including the jurisprudence of human rights in normative theories of human rights encourages a reformulation of practice-based theories to include more attention to the evolution of human rights at the national, as well as at the international, level. I suggest that much more attention should be paid to dialogic and dialectic processes that embrace sustained and reflexive contestation, pluralism, judicial institutions, and social activism. I propose ways to develop a partial détente between philosophical theories that are built on practice and those that are not, with the former providing an account in which principles drawn from ideal theories become incorporated into human rights practice, which, in turn, must be taken account of by practice-dependent theories. Examining judicial approaches to the supposed universal idea of dignity, finally, provides a more satisfactory explanation of how human rights are conceived to be both dependent on the state and to lie beyond it - to be part of international law and to lie beyond it. An analysis of international human rights law must take this complexity into account if a coherent and convincing explanation of the normativity of international human rights law is to stand any chance of being identified. 